\title{
Perancangan Sistem Informasi E-Learning pada SMAN ABC
}

\author{
TB E Zaki Baihaki ${ }^{1}$, Evy Nurmiati ${ }^{2}$ \\ ${ }^{1}$ Universitas Islam Negeri Syarif Hidayatullah Jakarta \\ zaki.baihaki17@mhs.uinjkt.ac.id \\ ${ }^{2}$ Universitas Islam Negeri Syarif Hidayatullah Jakarta \\ evy.nurmiati@uinjkt.ac.id
}

\section{ARTICLE INFO}

Article history:

Received 20 December 2010

Received in revised form 27 July 2021

Accepted 29 July 2021

Available online 31 July 2021

\begin{abstract}
The Covid-19 pandemic requires schools to divert their learning in their respective homes simultaneously with government regulations related to large-scale social access (PSBB) which aim to avoid crowds and add new clusters in the educational environment. This is a challenge for schools that do not yet have a bold learning platform and for teachers who still cannot use technology to provide their learning boldly. The web-based e-learning platform is expected to be able to assist teachers and students in carrying out learning without any technical guidance on its use. By using Rapid Application Development (RAD) in its design, it is hoped that it can produce an e-learning platform that is easy to use by teachers and students from SMAN ABC. This research is only up to the Design Workshop.
\end{abstract}

Keywords: E-Learning, RAD

\section{Introduction}

Di masa pandemi saat ini, banyak kegiatan-kegiatan yang dialihkan di rumah salah satunya yaitu kegiatan belajar di sekolah. Hal ini merupakan kebijakan pemerintah untuk mencegah penyebaran virus covid-19 karena dapat menyebabkan banyak kerumuman. Namun hal ini juga merupakan tantangan bagi pihak sekolah untuk tetap dapat melaksanakan pembelajaran secara jarak jauh dan harus mampu meningkatkan keaktifan siswa dalam melaksanakan kegiatannya. Keaktifan siswa dapat terlaksana dengan memanfaatkan teknologi yang interaktif dan sangat mudah digunakan oleh siswa.

E-learning merupakan pembelajaran yang memanfaatkan media elektronik seperti internet, tv interaktif dan audio untuk mengirimkan materi pembelajaran di mana saja dan kapan saja [1]. Tak hanya itu, E-learning juga diharapkan bukan sekedar menggantikan metode dan materi pembelajaran konvensional tetapi dapat menambah inovasi metode dan strategi baru dalam proses pembelajaran saat ini, terlebih lagi di masa sekarang yang mengharuskan belajar secara jarak jauh [2].

E-learning sudah ada sejak tahun 1970 , berbagai istilah dalam penggunaannya seperti online learning, internet-enabled learning, virtual learning, dan web-based learning. Terdapat 3 syarat penting untuk kegiatan pembelajaran yang menunjang penggunaan $e$-learning yaitu kegiatan pembelajaran dilakukan dengan menggunakan jaringan internet, tersedianya dukungan layanan belajar bagi peserta didik seperti handphone atau perangkat keras lain yang dapat mengakses

Received December 20, 2021; Revised July 27, 2021; Accepted July 29, 2021 
platform e-learning dan tersedianya tutor yang dapat membantu peserta didik apabila mengalami kesulitan dalam menggunakan platform e-learning [3].

Sistem dan aplikasi e-learning, biasa disebut sebagai sistem manajemen pembelajaran (LMS), adalah sistem perangkat lunak yang dapat divirtualisasikan untuk manajemen, dokumentasi, laporan rencana latihan, kelas, dan konten pelatihan untuk proses pengajaran rutin. Fungsinya terkait dengan manajemen proses pengajaran, seperti manajemen kelas, pembuatan materi, forum diskusi, sistem evaluasi dan sistem ujian berbasis online yang semuanya harus diakses menggunakan internet. Isi dan bahan ajar dalam LMS dapat berupa multimedia interaktif seperti multimedia pembelajaran yang dapat dioperasikan dengan perangkat keras atau konten berbasis teks (seperti buku teks) yang disimpan dalam LMS sehingga siswa dapat mengaksesnya kapanpun dan dimana pun [4].

Pada studi sebelumnya, e-learning digunakan sebagai sarana pelengkap dalam proses belajar mengajar, guru menggunakan platform Edmodo untuk memberikan pekerjaan rumah dan tes kepada siswa. Dengan menggunakan platform Edmodo, guru tidak lagi mengalami kesulitan dalam memberikan pekerjaan rumah atau tes kepada siswa. Selain itu, guru dapat memberikan ringkasan topik untuk digunakan siswa dalam pembelajaran mandiri. Respon siswa dalam menggunakan Edmodo sebagai media e-learning sangat baik, menurutnya Edmodo mudah dan menyenangkan [5].

Menurut hasil penelitian lainnya, penggunaan model pembelajaran e-learning merupakan terobosan baru dalam bidang belajar mengajar karena dapat meminimalisir perbedaan metode dan materi pengajaran, sehingga memberikan standar kualitas pembelajaran yang lebih konsisten. Sistem e-learning juga diperlukan untuk memprediksi waktu dengan dukungan teknologi informasi bahwa setiap orang sedang bergerak menuju era digital [6].

Pada penelitian yang dilakukan ini, perancangan sistem informasi $e$-learning untuk SMAN ABC diharapkan dapat membantu pihak sekolah dalam menerapkan platform e-learning untuk menunjang pembelajaran daring karena fitur-fitur pada $e$-learning sangat membantu para pengajar dan siswa dalam melakukan pembelajaran daring, seperti fitur materi, tugas, diskusi antara siswa dan guru mata pelajaran serta nilai akhir yang bisa dilihat langsung oleh siswa. Terlebih lagi di era pandemi saat ini platform e-learning dapat membantu kegiatan pembelajaran dari rumah. Peneliti menggunakan metode RAD (Rapid Application Development) dalam perancangan sistem informasi e-learning berbasis website untuk SMAN ABC. Penilitian kali ini hanya sampai tahap Design Workshop.

\subsection{Tinjauan Pustaka}

\subsubsection{Perancangan}

Perancangan adalah usulan pokok yang mengubah sesuatu yang sudah ada menjadi sesuatu yang lebih baik, melalui tiga proses: mengidentifikasi masalah mengidentifikasi metode untuk pemecahan masalah dan pelaksanaan pemecahan masalah [7].

\subsubsection{Sistem Informasi}

Sistem informasi adalah sistem yang memenuhi kebutuhan pemrosesan transaksi seharihari dan mendukung operasi dalam suatu organisasi, yang merupakan kegiatan manajemen dan strategis organisasi dan menyediakan laporan yang diperlukan kepada pihak eksternal tertentu. [8].

Sistem informasi menerima masukan data sesuai dengan perintah, instruksi dan mengolah data untuk mempublikasikan hasil, yang merupakan bagian dari peristiwa yang terjadi pada sistem informasi. Dalam suatu sistem informasi, kualitas informasi bergantung pada tiga hal yaitu akurat, tepat waktu dan relevan [8].

\subsubsection{E-Learning}

E-learning terdiri dari dua kata yaitu $\mathrm{E}$ dan learning. E merupakan singkatan dari elektronik yang berarti benda yang dibuat dengan menggunakan prinsip elektronik, sedangkan learning yang berarti pembelajaran atau belajar. Oleh karena itu e-learning mengacu pada proses pembelajaran dengan menggunakan computer dan perangkat elektronik lainnya [9]. Menurut Kartasasmita salah satu ciri-ciri e-learning yaitu memiliki perpaduan antara teknologi dengan 
berbagai terapan praktis dan dengan kemudahan akses ke sumber belajar, ke pengajar dan ke sesame peserta didik melalui internet. E-learning juga memiliki beberapa istilah lain seperti online course, online learning, internet enabled learning, virtual learning atau web-based learning. Namun beberapa istilah tersebut juga memiliki perbedaan dengan e-learning [10]. Penggunaan alat elektronik ketika melaksanakan kegiatan pembelajaran serta mengakses informasi yang berhubungan dengan materi pembelajaran di antara pengajar dan peserta didik disebut sebagai $e$ learning [11].

E-learning memiliki ciri-ciri sebagai berikut [12]:

1) Memiliki konten yang relevan dengan tujuan pembelajaran.

2) Menggunakan metode intruksional, misalnya penyajian contoh dan Latihan soal.

3) Membangun pemahaman dan kemampuan terkait dengan tujuan pembelajaran yang dilakukan secara individu ataupun kelompok.

4) Menggunakan elemen-elemen multimedia seperti kata-kata, gambar atau bahkan video untuk menyampaikan materi pembelajaran agar menghasilkan pembelajaran yang menyenangkan.

E-learning merupakan pembelajaran yang mempermudah pengajar dan peserta didik dalam pembelajaran jarak jauh karena materi pembelajaran disampaikan secara daring, yang bisa diakses kapan saja dan di mana saja oleh peserta didik.

\section{Research Method}

Metodologi yang digunakan dalam penelitian ini dengan menggunakan teknik pengumpulan data serta teknik pengembangan perangkat lunak.

\subsection{Teknik Pengumpulan Data}

Penggunaan teknik pengumpulan data bertujuan untuk memperoleh data-data yang dibutuhkan dalam pembuatan sistem. Teknik pengumpulan data yang digunakan antara lain:

1) Observasi

Observasi adalah suatu metode pengumpulan informasi atau data dengan mengamati dan mencatat fenomena yang terjadi pada objek pengamatan [13].Penelitian kali ini dilakukan observasi dengan melihat fenomena yang terjadi pada guru dan siswa di berbagai sekolah yang menggunakan platform e-learning. Tujuan observasi ini yaitu untuk mendapatkan informasi serta permasalahan-permasalahan yang ada sehingga dapat memudahkan dalam perancangan sistem $e$ learning ini.

2) Studi Pustaka

Studi Pustaka adalah kegiatan pengumpulan informasi dan data di mana sumbernya dapat berasal dari berbagai sumber kajian seperti buku, majalan, naskah, jurnal, artikel dan dokumen-dokumen yang di dalamnya berisi sumber kajian elektronik seperti rekaman berita dari radio, televisi, video dan media elektronik lainnya [14]. Dengan menggunakan metode ini diharapkan dapat membantu dalam memahami perancangan sistem informasi e-learning berbasis web

\subsection{Teknik Pengembangan Perangkat Lunak}

Berbagai tahapan metodologi pengembangan perangkat lunak akan membantu dan memfasilitasi desain sistem baru. Metode yang digunakan pada penelitian ini adalah Rapid Application Development (RAD), yaitu metode pengembangan perangkat lunak yang menekankan pada siklus pengembangan sistem yang singkat dan cepat. [15]. Berbagai tahapan metodologi RAD mulai dari tahap perencanaan syarat-syarat (Requirements Planning), workshop desain (Design Workshop) dan implementasi (Implementation) [16]. Pada Gambar 1 menunjukkan tahapan dari pengembangan metode RAD yang terdiri dari tiga tahapan utama. Pada penelitian yang dilakukan peneliti, peneliti menggunakan metode RAD hanya sampai tahapan Workshop Design. 


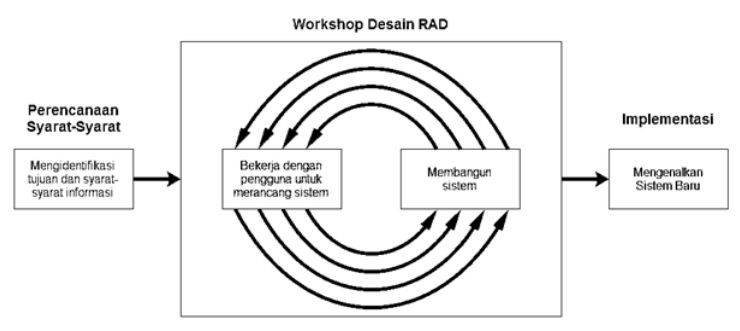

Gambar 1. Metode RAD [16]

Terdapat tiga tahapan dalam RAD yaitu, Perencanaan Syarat-Syarat (Requirements Planning) pada tahapan ini akan diketahui apa saja yang menjadi kebutuhan sistem dengan melakukan identifikasi kebutuhan informasi serta masalah yang dihadapi. Desain Workshop (Workshop Design) pada tahapan ini melakukan identifikasi solusi dan memilih solusi yang terbaik. Lalu membuat desain proses bisnis dan desain pemrograman. Implementasi (Implementation) setelah tahapan Workshop Design dilakukan, selanjutnya adalah melakukan tahapan implementasi sistem ke dalam Bahasa yang dimengerti oleh mesin dengan diwujudkan dalam bentuk program.

\section{Results and Analysis}

Pada perancangan sistem informasi e-learning yang menggunakan metode $\mathrm{RAD}$ memiliki beberapa tahapan di antaranya:

\subsection{Perencanaan Syarat-Syarat (Requirements Planning)}

Pada tahapan ini dilakukan identifikasi tujuan serta syarat-syarat informasi pada sistem yang akan dirancang. Identifikasi syarat-syarat informasi dilakukan dengan mengidentifikasi kebutuhan pengguna terhadap sistem yang dibangun. Identifikasi melalui analisa kebutuhan pengguna ini akan memberikan informasi syarat-syarat yang diperlukan dalam perancangan sistem informasi yang akan dirancang. Selain itu juga Analisa kebutuhan pengguna memiliki peran sebagai standar penilaian apakah sistem sudah berhasil atau tidak, karena sistem dinilai gagal apabila tidak dapat memenuhi kebutuhan pengguna [17].

Analisa kebutuhan dibagi menjadi dua yaitu analisis kebutuhan secara fungsional dan nonfungsional.

1) Kebutuhan Fungsional

Analisis kebutuhan secara fungsional bertujuan untuk dapat mengetahui arus informasi yang dapat diterapkan pada sistem guna memperoleh pemahaman tentang kerja sistem.

a) Kebutuhan Admin: admin dapat login menggunakan username dan password serta dapat mengakses dan mengelola website seperti mengelola user, konten, website dan hal-hal teknis lain yang tidak bisa dilakukan oleh user.

b) Kebutuhan User: user atau pengguna dalam hal ini yaitu Pengajar dan Peserta Didik yang dapat mengakses website $e$-learning dengan cara login menggunakan username dan password yang sudah diberikan oleh Admin. Pada menu pengajar terdapat beberapa fitur seperti upload materi, tugas dan forum diskusi. Sedangkan pada menu peserta didik terdapat beberapa fitur seperti daftar materi, daftar tugas, forum diskusi dan nilai akhir. Selain itu juga pengajar serta peserta didik dapat memanfaatkan forum diskusi terkait dengan mata pelajaran, atau tugas-tugasnya.

2) Kebutuhan Non-Fungsional

Analisis kebutuhan secara non-fungsional dapat dilakukan dengan menggunakan kategori dalam PIECES framework yaitu Performance, Information, Economics, Control Efficiency dan Service.

a) Performance: Sistem dapat melakukan pemberian materi, pengumpulan tugas serta berdiskusi secara cepat dan tepat. 
b) Information: Sistem dapat menampilkan informasi yang bermanfaat sebagai penunjang pembelajaran siswa. Informasi yang diberikan harus akurat, tepat waktu dan relevan.

c) Economics: Sistem informasi e-learning ini dapat menekan biaya-biaya seperti pembelian buku pelajaran. Karena dengan adanya sistem ini, peserta didik tidak perlu membeli buku lagi, hanya perlu mengakses mata pelajaran yang diunggah dalam bentuk dokumen.

d) Security: Sistem informasi memiliki user yang berbeda-beda, sehingga aman untuk digunakan oleh pengajar dan peserta didik. Dapat dipantau oleh pihak sekolah karena pengelolaan dilakukan langsung oleh pihak sekolah.

e) Efficiency: Dapat membantu pihak sekolah dalam pelaksanaan aktivitas pembelajaran di rumah karena seluruh sistemnya sudah terintegrasi, mulai dari pengumpulan tugas, pemberian materi, kuis atau ujian, forum diskusi yang dapat dilakukan antara pengajar maupun peserta didik serta peserta didik dapat melihat nilai akhir mereka di dalam platform ini.

f) Service: Dengan dirancangnya sistem ini diharapkan mampu melaksanakan pembelajaran jarak jauh di rumah masing-masing karena dapat diakses secara mudah.

\subsection{Desain Workshop (Workshop Design)}

Pada tahapan ini terdiri dari dua tahapan yaitu perancangan sistem dan tahapan pembangunan sistem.

1) Perancangan Sistem

Perancangan sistem biasanya terdiri dari dua antarmuka yaitu frontend yang ditujukan untuk user serta backend yang ditujukan untuk admin. Pada tahapan ini termasuk juga tahap perancangan basis data yang akan digunakan untuk perancangan sistem. Basis data merupakan kumpulan dari data yang di dalamnya membentuk hubungan atau relasi antara satu data dengan data lain dalam sebuah perusahaan atau organisasi [18].

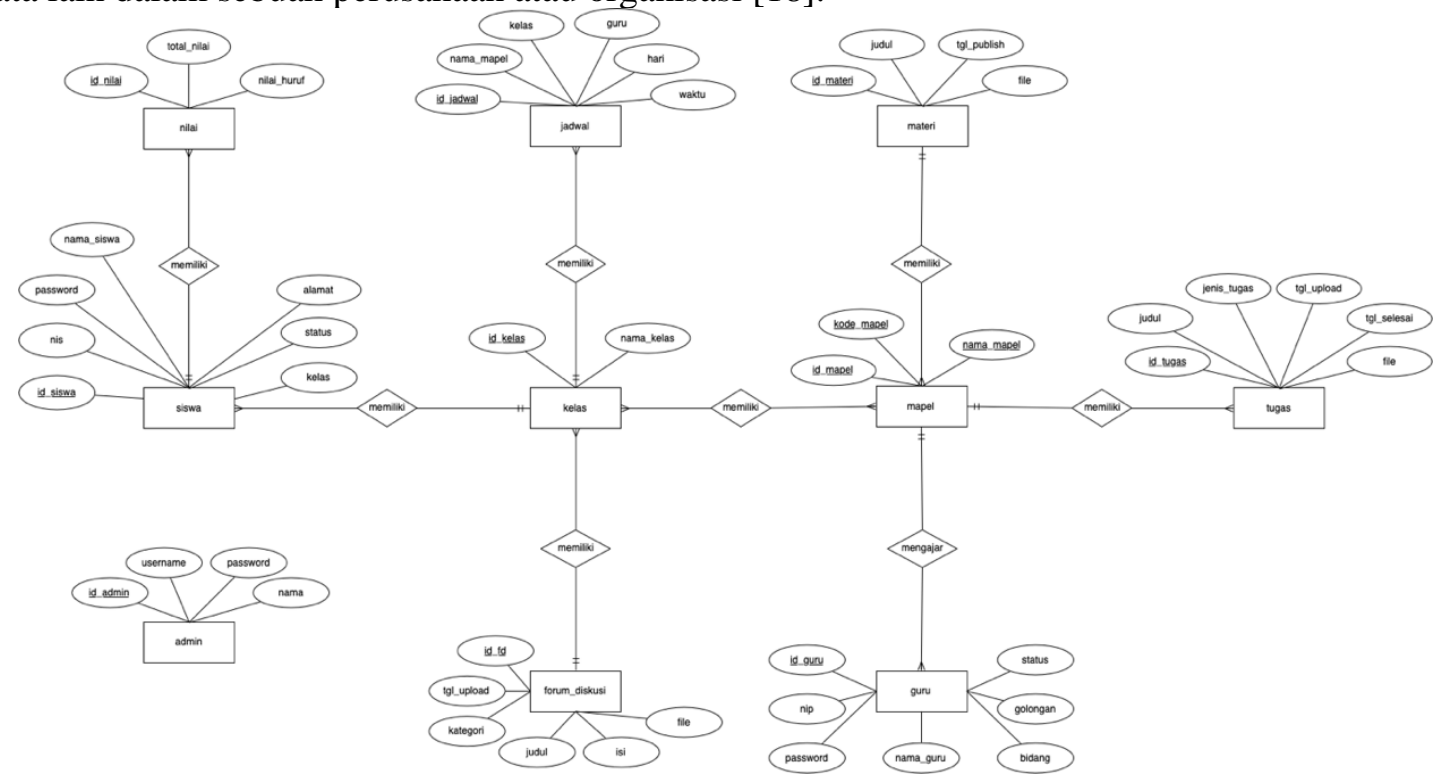

Gambar 2. ERD Sistem Informasi E-Learning

Perancangan basis data pada Gambar 2 menunjukkan hubungan antar himpunan entitas yang saling terbentuk. Tahapan selanjutnya setelah merancang ERD yaitu mentransformasikannya ke dalam bentuk Logical Record Structure (LRS) yang bertujuan untuk mengetahui atribut yang berperan sebagai primary key dan foreign key, serta dapat mengetahui secara jelas nilai kardinalitas dari masing-masing hubungan.

TRANSFORMATIKA Vol. 19, No. 1, July 2021: $38-47$ 


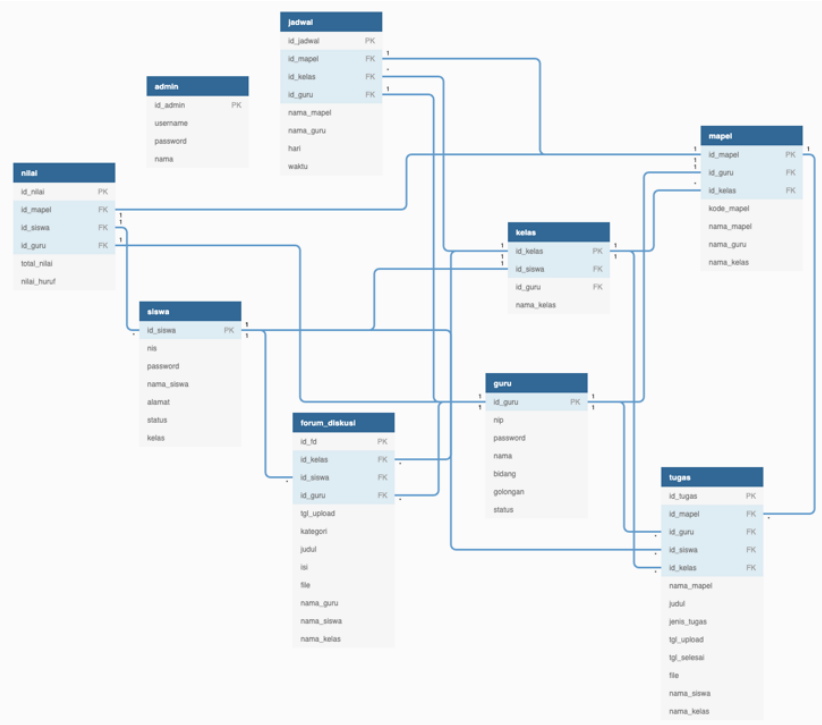

Gambar 3. LRS Sistem Informasi E-Learning

2) Membangun Sistem

Pada tahapan ini bertujuan untuk melakukan desain storyboard. Adapun storyboard yang dirancang terdiri dari tampilan login, dan tampilan lainnya dibagi ke dalam 2 bagian yaitu antara pengajar dan peserta didik. Untuk pengajar berisikan tampilan posting materi, posting tugas, daftar tugas siswa dan forum diskusi. Lalu untuk tampilan peserta didik berisikan daftar materi, daftar tugas, forum diskusi dan nilai akhir.

1.1 Storyboard Halaman Login

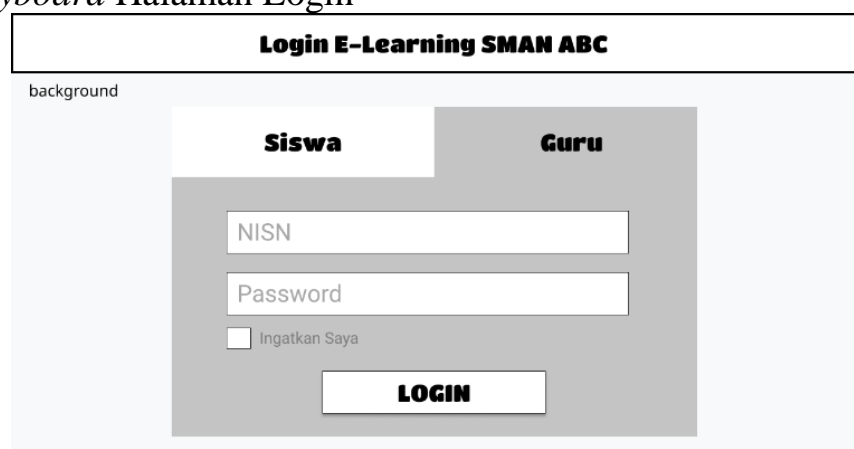

Gambar 4. Tampilan Halaman Login

1.2 Storyboard Posting Materi (Pengajar)

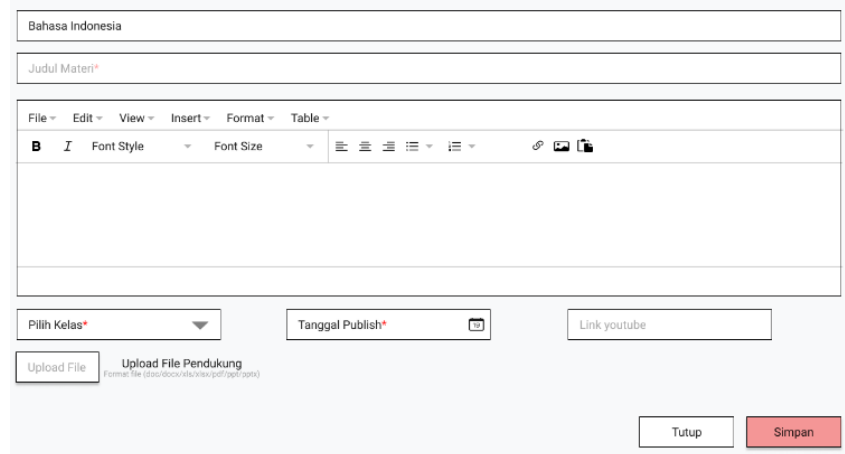

Gambar 5. Tampilan Halaman Posting Materi oleh Pengajar

Perancangan Sistem Informasi E-Learning pada SMAN ABC (TB E Zaki Baihaki) 
1.3 Storyboard Posting Tugas (Pengajar)

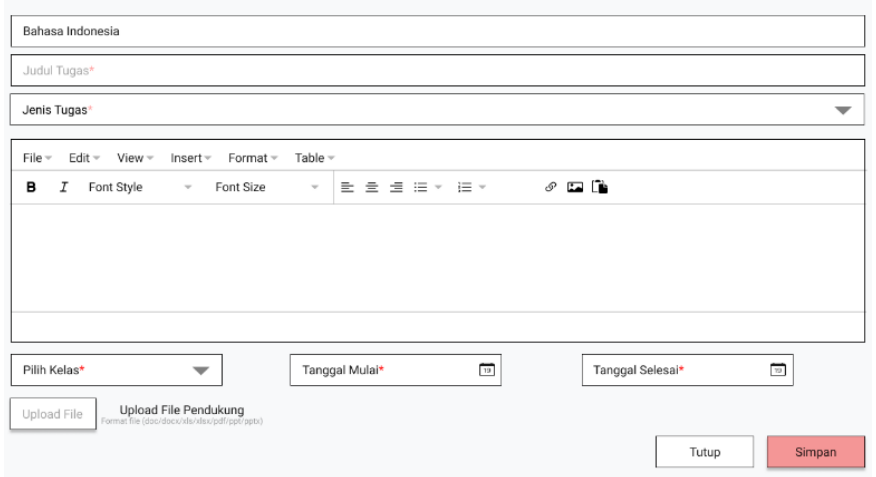

Gambar 6. Tampilan Halaman Posting Tugas oleh Pengajar 1.4 Daftar Tugas Siswa (Pengajar)

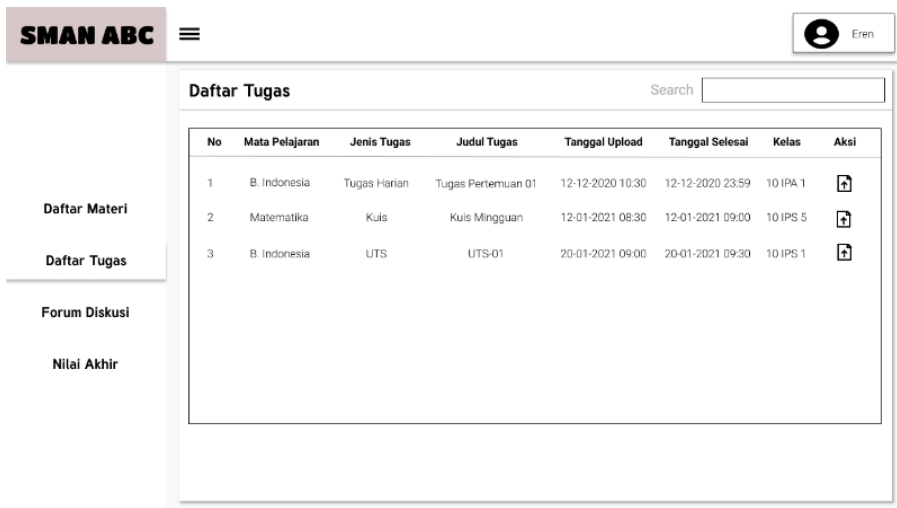

Gambar 7. Tampilan Halaman Daftar Tugas Siswa

1.5 Forum Diskusi (Pengajar)

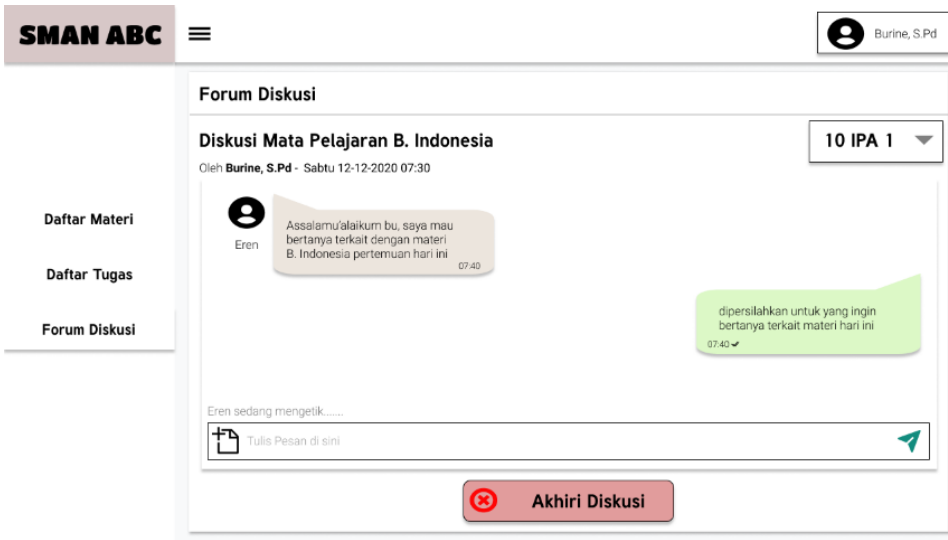

Gambar 8. Tampilan Halaman Diskusi Mata Pelajaran

TRANSFORMATIKA Vol. 19, No. 1, July 2021: $38-47$ 
1.6 Daftar Materi (Peserta Didik)

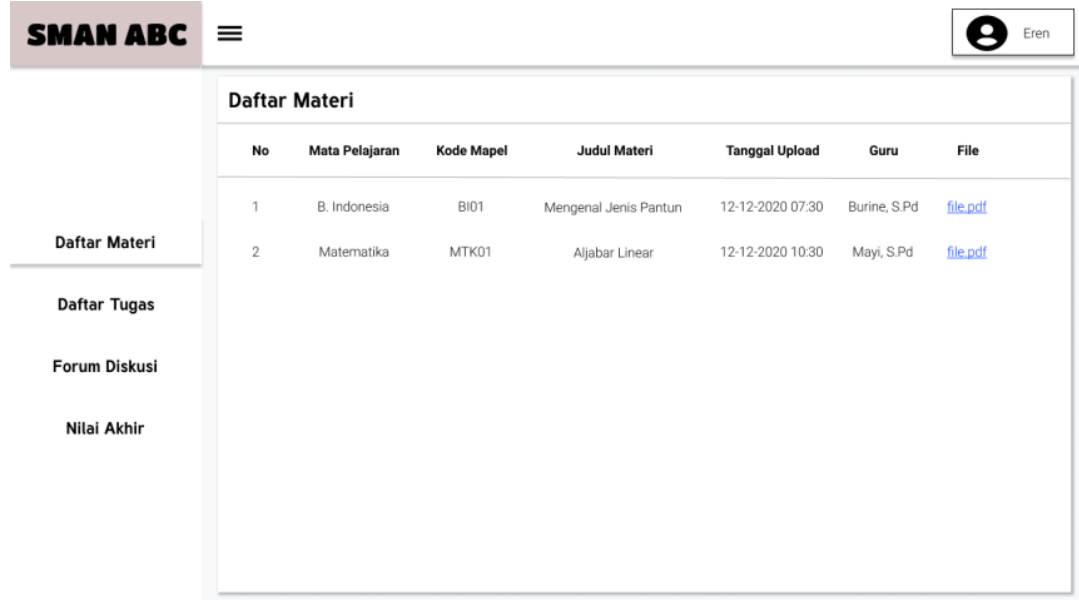

Gambar 9. Tampilan Halaman Materi Peserta Didik

1.7 Daftar Tugas (Peserta Didik)

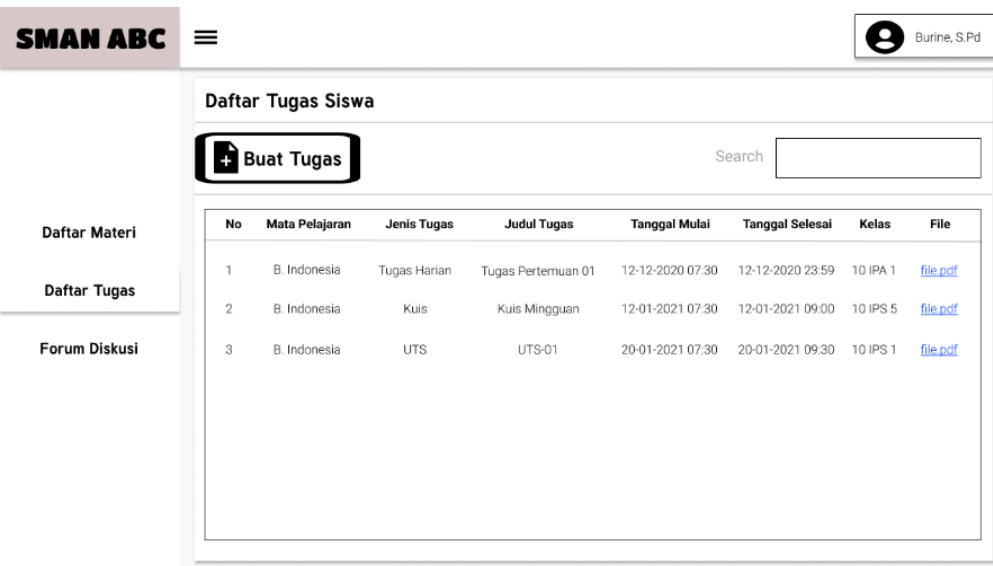

Gambar 10. Tampilan Halaman Daftar Tugas Peserta Didik 1.8 Forum Diskusi (Peserta Didik)

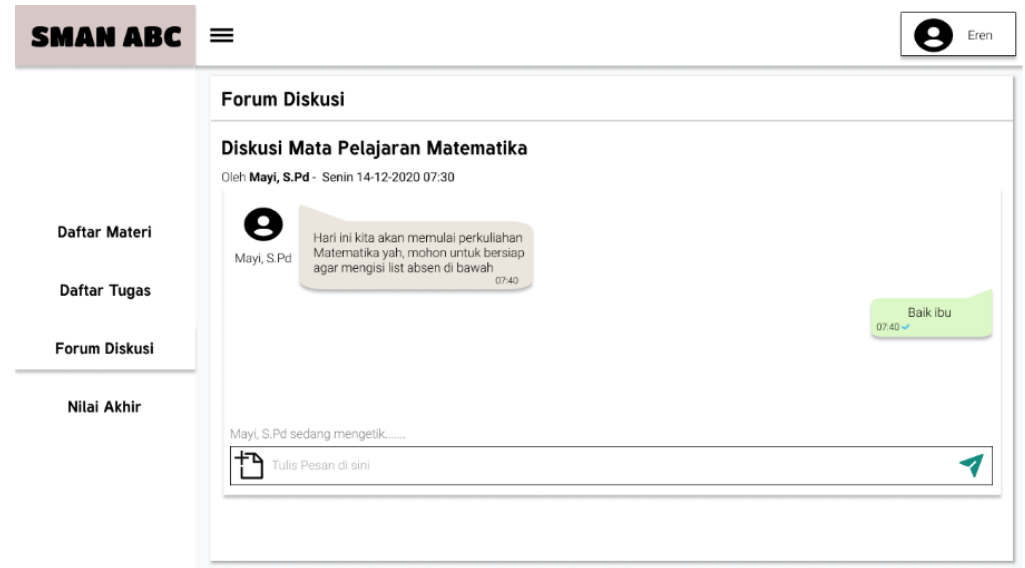

Gambar 11. Tampilan Halaman Diskusi Mata Pelajaran 
1.9 Nilai Akhir (Peserta Didik)

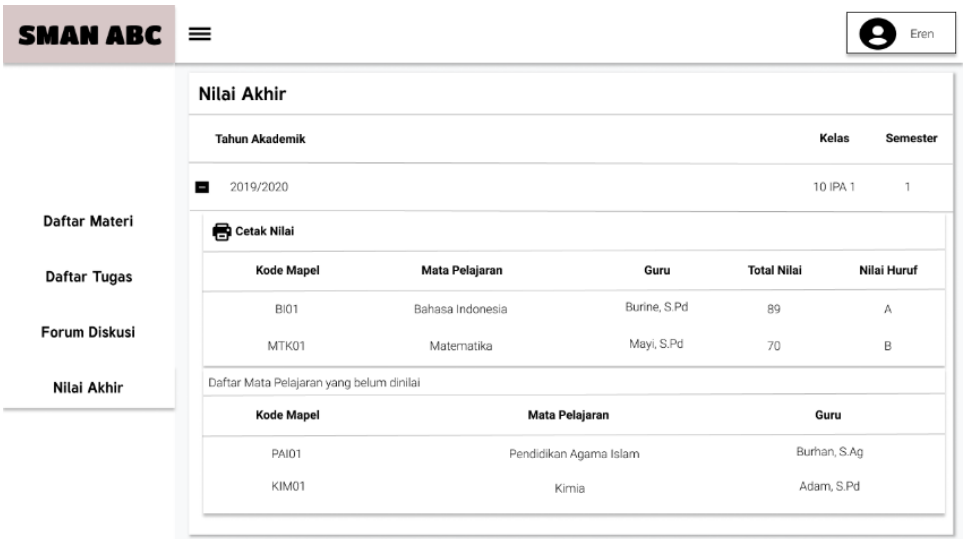

\section{Kesimpulan}

Gambar 12. Tampilan Halaman Nilai Akhir Peserta Didik

Berdasarkan hasil dan pembahasan yang sudah diuraikan sebelumnya, dapat disimpulkan bahwa penggunaan platform e-learning ini sangat membantu sekolah yang menerapkan pembelajaran di rumah. Penggunaan sistem informasi ini juga sudah terintegrasi satu sama lain serta akan membantu memberikan informasi yang akurat, cepat dan relevan.

Saran dari peneliti untuk penelitian selanjutnya yaitu pengambilan studi kasus yang diharapkan merupakan sekolah yang nyata, dan terdaftar sehingga memudahkan ketika melakukan penelitian. Penelitian ini hanya sampai tahap Workshop Design diharapkan pada penelitian selanjutnya dapat dilakukan sampai pada tahap Implementasi agar sistem ini dapat digunakan oleh pihak sekolah yang dapat membantu menunjang pembelajaran daring di era pandemi saat ini.

\section{References}

[1] P. Astuti and F. Febrian, "Blended Learning Syarah: Bagaimana Penerapan dan Persepsi Mahasiswa," J. Gantang, vol. 4, no. 2, pp. 111-119, 2019.

[2] B. Indrayana and A. Sadikin, "Penerapan E-Learning Di Era Revolusi Industri 4.0 Untuk Menekan Penyebaran Covid-19:(The Application of E-Learning in the Era of the Industrial Revolution 4.0 to Suppress the Spread of Covid-19)," Indones. J. Sport Sci. Coach., vol. 2, no. 1, pp. 46-55, 2020.

[3] W. Hartanto, "Penggunaan E-Learning Sebagai Media Pembelajaran," J. Pendidik. Ekon. J. Ilm. Ilmu Pendidikan, Ilmu Ekon. dan Ilmu Sos., vol. 10, no. 1, 2016.

[4] M. Yuliani et al., Pembelajaran Daring untuk Pendidikan: Teori dan Penerapan. Yayasan Kita Menulis, 2020.

[5] Z. Ainiyah, "Penggunaan edmodo sebagai media pembelajaran e-learning pada mata pelajaran otomatisasi perkantoran di smkn 1 surabaya," J. Adm. Perkantoran, vol. 3, no. 3, 2015.

[6] A. H. Elyas, "Penggunaan Model Pembelajaran E-Learning Dalam Meningkatkan Kualitas Pembelajaran," War. Dharmawangsa, no. 56, 2018.

[7] S. Sukmawati and D. Susianto, "Perancangan Sistem Pemesanan E-Tiket Pada Wisata Di Lampung Berbasis Web Mobil," J. ONESISMIK, vol. 2, no. 2, pp. 60-71, 2019.

[8] H. M. Jogiyanto, "Analisis dan Desain Sistem Informasi: Pendekatan Terstruktur," Andi, Yogyakarta, 2005.

[9] L. Simanihuruk et al., E-Learning: Implementasi, Strategi dan Inovasinya. Yayasan Kita

TRANSFORMATIKA Vol. 19, No. 1, July 2021: $38-47$ 
Menulis, 2019.

[10] B. Kartasasmita, "Catatan Pengembangan e-learning dalam Budaya Belajar Kini," in Makalah Seminar pada tanggal, 2003, vol. 8.

[11] P. Yaniawati, "E-Learning Alternatif Pembelajaran Kontemporer," Bandung Arfino Raya, 2010.

[12] H. A. H. Sanaky, “Media pembelajaran.” Yogyakarta: Safiria Insania Press, 2009.

[13] S. Mania, "Observasi Sebagai Alat Evaluasi dalam Dunia Pendidikan dan Pengajaran," Lentera Pendidik. J. Ilmu Tarb. dan Kegur., vol. 11, no. 2, pp. 220-233, 2017.

[14] M. Kun and J. Suryawati, "Sosiologi untuk SMA dan MA Kelas XI," Jakarta: Erlangga, 2006.

[15] D. Kurniadi and A. Mulyani, "Implementasi Pengembangan Student Information Terminal (S-IT) Untuk Pelayanan Akademik Mahasiswa," J. Algoritm., vol. 13, no. 2, pp. 437-442, 2016.

[16] S. Kosasi and I. D. A. E. Yuliani, "Penerapan Rapid Application Development Pada Sistem Penjualan Sepeda Online," Simetris J. Tek. Mesin, Elektro dan Ilmu Komput., vol. 6, no. 1, pp. 27-36, 2015.

[17] R. Yufita and A. Andriani, "Sistem Informasi dan Promosi Berbasis Web pada Family Mebel Magelang,” Indones. J. Netw. Secur., vol. 1, pp. 1-6, 2016.

[18] A. Andriani, "Manajemen Basis Data," 2019. 